\title{
Spaces of alienation: Dispossession and justice in South Africa
}

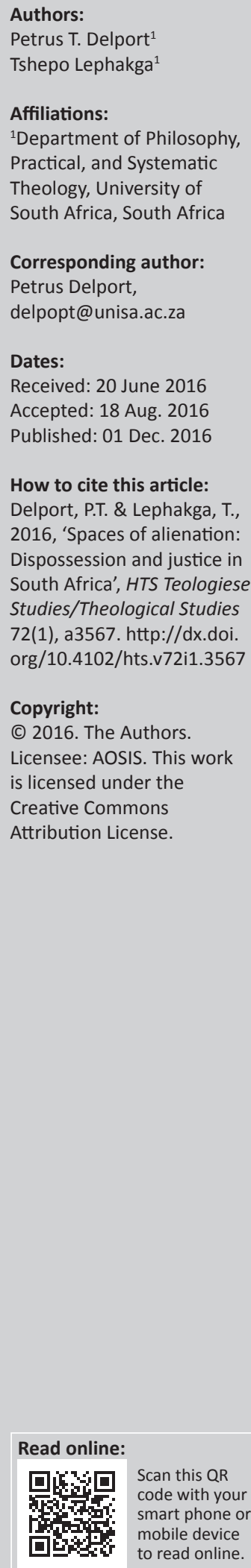

Theories and philosophies of space and place have seen a rise in prominence in recent times, specifically in the disciplines of theology, law and philosophy. This so-called spatial turn in contemporary theory is one that attempts to think through the vicissitudes and conceptual lineages related to the existence of space as both a physical and a social reality. The politics of space in South Africa, however, cannot be thought of separately from the concept of alienation. South Africa is a space whose existence is predicated upon a relationship of alienation to its located place. South Africa, like most other settler colonies, is a space that was created through occupation and alienation: the occupation of a territory and the alienation of the indigenous people from this occupied territory. This relationship of alienation is not only observable in the physical reality engendered by this occupied space but also by its social reality. In this paper we reflect on the intersections of the physical and social manifestations - in Bourdieu's sense - of an occupied space and consider its effects of alienation on the indigenous people. To this end we will proceed to interrogate current South African geographical markers - such as the existence of townships and suburbs - from its positionality within the history of South Africa as an occupied space. To discern a theological agenda for the issue of spatial justice would also require an investigation into the theological agenda that prohibited the realisation of spatial justice in South Africa or, in other words, the religious reconciliation preached post-1994 at the expense of justice.

\section{Introduction}

Theories and philosophies of space and place have seen a rise in prominence in recent times, specifically in the disciplines of theology, law and philosophy. This so-called spatial turn in contemporary theory is one that attempts to think through the vicissitudes and conceptual lineages related to the existence of space as both a physical and a social reality. The politics of space in South Africa, however, cannot be thought of separately from the concept of alienation (Biko 2004; Fanon 2001 Lephakga 2012; Murray 1991; Pheko 1986). South Africa's existence is predicated upon a relationship of alienation to its located place (Biko 2004; Fanon 2001; Lephakga 2012; Murray 1991; Pheko 1986). South Africa, like most other settler colonies, is a space that was colonially created through occupation and alienation: the occupation of a territory and the alienation of the indigenous people from this occupied territory (Biko 2004; Lephakga 2012; Pheko 1986). This relationship of alienation is not only observable in the physical reality engendered by this occupied space but also in its social reality. Our aim in this paper is to reflect on the intersections of the physical and social manifestations of an occupied space and consider its effects of alienation on the indigenous people.

Our approach in addressing this particular problem of alienation and space follows, in Clodovis Boff's (1996:1) terms, a 'Methodology of the Theology of Liberation'. For Boff, the 'liberation in liberation theology denotes first of all social liberation. This is the question of our time. And this was the first question from which the theology of liberation sprang' (Boff 1996:4), and this theology of liberation 'develops in three fundamental moments, corresponding to the three "times" of the celebrated pastoral method: seeing, judging, and acting' (Boff 1996:11). These three mediations cited by Boff, the particular instruments of a theological construction, have their roots in the fundamental question of social liberation. For that reason all reflection from a theology of liberation must start with the socio-analytic method: 'liberation theology must begin by stooping down and examining the actual conditions in which the oppressed find themselves, whatever these conditions may be' (Boff 1996:11). The second methodological moment, or mediation, is the hermeneutic mediation, in which the question is asked, '[w] hat does the word of God say about this situation?' (Boff 1996:15). The first two steps outlined by Boff are thus to present a historical

Note: This article is part of the Special Collection titled 'Spatial Justice and Reconciliation', sub-edited by Stephan de Beer, of the Department of Practical Theology and the Centre for Contextual Ministry, University of Pretoria. 
and social analysis of the question of oppression before moving towards a theoretical reflection; it is only after these first two steps that the question of action, the practical mediation, can be engaged. It is following from these three mediations that we will engage the question of spatial justice and the possibilities of an agenda for a spatial theology. To this end we will proceed to interrogate current South African geographical markers - such as the existence of townships and suburbs - from their positionality within the history of South Africa as occupied space. To discern a theological agenda for the issue of spatial justice would also require an investigation into the theological agenda that prohibited the realisation of spatial justice in South Africa, or in other words the religious reconciliation preached post-1994 at the expense of justice.

\section{Colonial epistemology and global orders}

The socio-analytic mediation related to our point of investigation in this paper is the history of conquest and alienation in South Africa. This is the historical basis from which the question of spatial justice arises in our present juncture. The history of conquest and alienation in South Africa, however, must be understood together with a history of world formation and division through the era of colonial conquest. The division of the globe into the 'new' and 'old' worlds was a process that followed the euphemistically named age of discovery and the globalisation of European law and order. The division of the globe through a series of legal treaties and division - rayas, amity lines and the construction of the Northern and Southern Hemispheres was unilaterally promulgated by European powers and exported to the rest of the globe (Schmitt 2006:86-99). European legal minds and social theorists determined what was considered as international law and as acceptable conditions for rationality. Francisco Vittoria, considered as one of the founders of the discipline of international law, ${ }^{1}$ wrote his initial texts as justifications of Spanish incursions into the Americas by breaking from scholastic divine law and establishing a concept of international law based on the minimum condition of the human capacity to rationality (Anghie 2004:17-18). While Vittoria may have extended this human faculty to the Amerindians, he did so only to enable them to strive to the highest form of rationality, which in the fifteenth century, for Vittoria, was Spanish. This type of reasoning attempts to extend Europe, or the Old World, into global power through the process of colonisation and conquest of the so-called New World.

For Dussel (1985:1-9) this relationship between the New World and the Old World can be re-inscribed as a construction of the world into the 'periphery' and 'centre', where the periphery is the new, non-European world, and the centre is the old, conquering powers of Europe. Dussel (1985:5-6) argues that this conception of the formation of the colonial construction of the world is one that follows the hierarchical social division of Greek society, ${ }^{2}$ more specifically the association of 'Being, the divine, the political and the eternal' as identical. Dussel (1985:6) argues that this conception of being as totality - Parmenides' 'Being is; non-Being is not' was naturalised in Greek culture and civilisation as an allencompassing totality. The idea of the world and the totality of its being was to be found only in the Graeco-Roman city: 'Being extends as far as the frontiers of Hellenism. Over the horison is non-Being, uncivilisation, Europe and Asia' (Dussel 1985:5). This naturalisation of being into Greek culture then also had the effect of justifying social structures and divisions ontologically and not merely politically.

In ancient Greek society, human beings were not considered equal and could not occupy the same social classes in society (Aristotle 1962:25-40; Hansen 1992:129-160; Hunt 2002:1-19; Lephakga 2015:151-156; Scheidel 2008:1-25). Greek society was constructed into a hierarchy with men born into noble families occupying the highest strata in this hierarchy, followed by children born into noble families and, finally, women. Slaves were considered the lowest in the Greek social hierarchy and were not included in the concept of demos, or the people who were able to enter into political and social life. Women were thus considered to be the lowest form of human being, whereas slaves were not considered human at all; slaves were outside of the consideration of being a human being though not outside of the totalising image of being itself. The conflation between 'Being, the divine, the political and the eternal' meant that the slaves were considered as part of the being of Greece exclusively as slaves; they were included in the totalising image of Greek Being only as slaves, since this image of Greek Being required slavery in its construction and understanding of itself (Aristotle 1962:25-40; Dussel 1985:1-9; Hansen 1992:129-160; Hunt 2002:1-19; Lephakga 2015:151-156; Scheidel 2008:1-25). It is perhaps Plato, one of the foundational thinkers of Western thought, who serves as a good example of this hierarchical nature of Greek thinking. Accordingly, in Plato's The Republic (2007), for society to function to its utmost and strive towards the world of forms, it needs to be constructed and divided into differing realms and classes. Plato illustrates these different realms and classes by using the metaphor of a ship in Book VI of The Republic (sections 488e-489d). According to Plato, a state can be likened to a ship, with the population the illiterate shipowner, the politicians the rowdy and unruly sailors, and the navigator the philosopher king who plots the way. The navigator or philosopher king would have to have access to the noble history and teachings of the nobility and come from the higher strata of society; the philosopher king thus has to be a man. While children from noble families have an opportunity to rise to this level due to their possible proximity to noble background, women are not considered as part of the official political decision-making section of society, no matter how noble their background.

\footnotetext{
2.For Aristotle, the great philosopher of the classical period, reared to accept slavery and pursue self-centeredness, the Greek was human. The European barbarians were not human, because they were unskilled; nor were Asians human, because were not human, because they were unskilled; nor were Asians human, because
they lacked strength and character; slaves were not human either; women were they lacked strength and character; slaves were not human either; women
halfway human and children were only potentially human. (Dussel 1985:4)
} 
The true faculty of reasoning was thus only extended to Greek men, who, as a result of their proximity to noble background and its teachings, became the thinking beings those whose intellect overpowered their emotions (Hansen 1992; Hunt 2002:1-19; Lephakga 2015:151-156; Scheidel 2008:1-25). Entering into the political space of decisionmaking was also reserved for those who had the privileged access to reason and nobility. The self-assumed status of a man in Greek society endowed their natural beings as guardians of those in the lowest strata of the society. Slaves, on the other hand, were forever bound to their role as unintelligent and subservient beings whose emotions overpowered their intellect. The slave could never become other than a slave since history, family background and the accident of birth had already passed judgement on the position that he or she would be allowed to occupy (Dussel 1985:1-9; Lephakga 2015:151-156). Dussel's (1985:3-8) argument is that this conception of Greek society and the totalising image of Being aided in the construction of a colonial epistemology and the expropriation of the idea of Being as Greek to Being as European. The colonial epistemology that divided the globe into hierarchies of existence was, in turn, a method of moral justification for colonisation.

The division of the world into the centre and the periphery was also the process of institutionalising the supremacy of those in the centre through self-endowment based by and large on an extrapolation and consequent adoration of ancient Greek and Roman culture by European philosophers, theologians and jurors, of guardianship through empire building. ${ }^{3}$ The division of the globe and the establishment of Europeas thecentre requirefirst, or rathercontemporaneously, the appropriation through dispossession of all land decreed as non-European. ${ }^{4}$ It is for this reason that one cannot engage the question of space in settler colonies without considering it within the bigger movement of conquest, colonisation and the universalisation of Europe. Space, specifically in the form of land, was the central point of contention between conquerors and the conquered. As Dussel (1985:1) thus observes, '[s]pace as a battlefield, as geography studied to destroy an enemy, as a territory with fixed frontiers, is very different from the abstract idealisation of empty space of Newton's physics or the existential space of phenomenology'. It is for this reason that we now turn to a more particular reading of South Africa as an occupied space, a space where liberation is still outstanding.

\section{Accumulative strategies in an occupied Azania}

The history of the systematic conquest of South Africa must, as pointed out above, be seen in light of the division of the globe into the centre and the periphery, since the

3.Vittoria's de facto universalisation of European - at that stage Spanish - conception of reason and rationality to the Amerindians were a prime example of this disposition that aided the euphemistically named 'age of discovery'.

4.The series of decrees and legal instruments used to justify the colonial conquest is discussed by Carl Schmitt in his Nomos of the Earth (2006), particularly Part II: The Land Appropriation of a New World. colonial epistemology referred to above institutionalises the supremacy of the occupants of the centre in relation to the subservient status of those in the periphery. Motsoko Pheko (1986:25-34) and Sampie Terreblanche (2002:153) point out that both the Portuguese and the Dutch took voyages to the continent - particularly the Cape coast - initially under the banner of mercantilist expansion. This is by no means to say that these initial voyages of conquest were not part of the colonial mission but rather that, throughout the history of South Africa, colonialism adopted a number of forms and methods. These forms and methods are what Terreblanche (2002:14) refers to as 'successive systemic periods' of dispossession in South Africa. Terreblanche identifies six successive strategies of accumulation that covers the period from the 16th century to the present, all based on the basic premise of annexing land and expropriation resources.

In the 16th century the trade route around the Cape was monopolised by the Portuguese and their predominant slave trading economy; 'from the 16th to the 19th centuries, Portugal exported more than 5 million slaves to America ...' (Terreblanche 2002:153). During the

early 1700s the British East India Company (BEIC, established in 1600), and the Dutch Verenigde Oostindische Compagnie (VOC, established in 1602) moved in to contest the Portuguese monopoly [on the trade route to the southern tip of Africa], but the latter managed to retain a significant portion of it during the $17^{\text {th }}$ century. (Terreblanche 2002:153)

Pheko (1986:25-34), in capturing the notion that 'monopoly goes hand in hand with colonialism', noted that Jan van Riebeeck and the Dutch East India Company were not philanthropists out to uplift the indigenous people; they were, like all capitalists and traders, out to make money by whatever means necessary. The VOC was a mercantile capital-driven company, uniting a number of Dutch commercial undertakings, backed by the Dutch government and military, that developed into one of the largest and most profitable commercial companies of the seventeenth and early eighteenth centuries. Their mercantilist mentality was what characterised this first systematic strategy of accumulation by European powers in South Africa. Accordingly, this mercantilist mentality dictated that the VOC was allowed to trade on the land they occupied and that if their economic interests were threatened by any of the indigenous people, they could use whatever means necessary to protect their interests.

This colonial approach was not only adopted by the VOC but was also used by the British during the eighteenth and nineteenth centuries. It must be noted that when the VOC established its post at the Cape coast, the land belonged to the indigenous people, most of whom were hunter-gatherers. The VOC initially depended on the indigenous people for land and cattle and the company was anxious to avoid costly wars with these indigenous people. The VOC initially adopted a policy that required leaders in the colonies to treat the indigenous people with respect and do nothing to disturb their cultural integrity and socio-economic stability (Pheko 1986:25-34; 
Terreblanche 2002:153-178). This policy was adhered to until the VOC released some of its employees from their contracts and set them up as 'free burghers' (or independent farmers) outside of the space annexed by the VOC. The first Dutch settlers were all under the jurisdiction of the VOC and the Heeren XVII (literally translated as the 17 lords of the company', or 'directors' in modern parlance) and also reported to them and took orders from them. In 1657, the Heeren XVII instructed the VOC commander at the Cape, Jan van Riebeeck, to release several individuals from their company contracts and settle them as free burghers outside the jurisdiction of the VOC. Terreblanche argues that this specific act of settling the free burghers can be considered as

the beginning of a colonial process of land deprivation that continued for more than 250 years, and sparked many violent conflicts. This process culminated in the Land Act of 1913 that set aside only $8 \%$ of South Africa's total land area as native reserves. (Terreblanche 2002:155)

The accumulative strategy of the VOC from 1657 to 1800 was, as already mentioned, based on the political ideology of mercantilism and the establishment of a Dutch colony in the Cape. Although the colony was established and the VOC did enjoy some of the colonial spoils of their accumulation strategy, the colony would soon change hands and be reorganised yet again. During the end of the eighteenth century the British annexed the Cape at the same time that their status as the leading imperialist and industrialist country began to be cemented. They had to consequently break patterns of mercantilist accumulation by introducing concepts such as an international market and a labour market (Terreblanche 2002:180). Regarding the spatial organisation of the country, the British also had an immense effect and enduring legacy. In 1894, after the discovery of diamonds and gold in the north of the country, Cecil John Rhodes passes the Glen Gray Act to remove '[n]atives from that life of sloth and laziness, teaching them the dignity of labour' (Rhodes quoted in Webster 1983:10). This Act in effect created the first homeland by turning the Glen Grey area into a labour reserve and creating a disenfranchised class working on the mines. The lines of demarcation drawn by the Glen Gray Act would later be confirmed and ratified through several legal instruments that include the Native Land Act of 1913, the Urban Areas Act of 1922 and the Group Areas Act of 1950. It was in 1910 that the British accumulative strategy of imperialism evolved, after some years of dormancy, into what is known today as 'apartheid'.

The importance of considering this historical movement following Terreblanche's idea of accumulative strategies is to show that apartheid was not an exceptional moment in South African history but rather a different form of the same strategy of colonialism in South Africa. It is also important as it shows how South Africa was spatially organised and divided in order to serve a specific form of white capital accumulation and resource extraction. As a result of this conquering of the territory through colonisation, indigenous people were made pariahs in the land of their birth, a process that was merely formalised with the passing of the Land Act of 1913 in South Africa (Lephakga 2013). This accumulative strategy was cemented with the victory of the National Party in 1948, which also inaugurated the legalisation of colonial apartheid. Considering the formulation of a 'colonial epistemology' as discussed above, it can be shown that the apartheid government legally institutionalised, through apartheid, the supremacy of the conquerors and constitutionalised a policy that not only forcefully removed the indigenous people from their ancestral land, which defined their Being, but that also made them pariahs in the main economy of their own land. This was achieved mainly through the instrument of the Native Land Act of 1913, as well as the consequent Urban Areas Act of 1922 and the Group Areas Act of 1950. Together with these two pieces of legislation, the Bantu Authorities Act No. 68 of 1951 was the other main piece of legislation used by the National Party (NP) government to entrench a colonial spatial division and ensure that the most economically developed and agriculturally arable land was to be in the possession of the white minority.

This colonial division of South Africa created what Frantz Fanon (2001:29-31) has referred to as 'settler and native towns'. Fanon illustrates this spatial division when he points out that 'the settlers [sic] town is well-fed-town, an easy-going town; its belly is always full of good things. The settlers town is a town of white people, of foreigners', whereas in contrast 'the town belonging to the colonised people ... is a place of ill fame' (Fanon 2001:30). The settler town is beautiful and well fed for a particular reason, namely to maintain the supremacy of the colonisers and entrench and confirm the global division. Fanon's observations can be almost directly supplanted to South Africa and the establishment of Bantustans as per the Bantu Authorities Act of 1951. The Bantu Authorities Act effectively ensured a situation whereby

[a]ll Africans were declared to belong to one of the 10 Bantustans, with native language and tribal origins as the deciding factors. In this way, Africans were deprived of their South African citizenship and instead became citizens of the designated homeland. [Africans] had no place or rights in South Africa, but were simply regarded as migrant workers who, if unemployed, had to return to their Bantustans. (Lephakga 2012: 58-59)

The legacy of these Bantustans is still visible today from the micro level in access to facilities to the macro level in the division of the country. ${ }^{5}$

The enduring legacy of the spatial divisions brought about by successive colonial regimes in South Africa was supposedly brought to an end with the negotiated settlement of 1994 and the consequent adoption of the new constitution in 1996. It is our argument in this paper, however, that the negotiated settlement and new constitution are completely in line with the colonial project of ensuring a division both

5 The legacy and history of the Bantustans and the annexation of land by colonial fores is, how her not merly a materia and political (2012:65) for an analysis of the consequences of Bantustans and Lephakga (2012:65) for an analysis of the consequences of Bantustans and this spatial division on the level of identity and the concept of self of the indigenous conquered people. 
materially and spatially between the white conquering class and the black conquered class. This is the most enduring legacy of colonialism in the present: the continued existence of 'native' and 'settler' towns in the form of townships and suburbs, black and white spaces, conquered spaces. The negotiated settlement was not some kind of miracle but rather another reconfigured accumulative strategy based on neoliberal policies (Lephakga 2015:95-144; Terreblanche 2002:95-139). Under this new accumulative strategy the market is open to all to compete, while certain players have over 350 years' experience and material benefit on their side (Lephakga 2015:95-144; Terreblanche 2002:95-139). The political spectacle and so-called miracle served as a political 'smokescreen' to protect the division and institutionalised economic disparity that existed in the country (Lephakga 2015:95-144; Terreblanche 2002:95-139). The negotiated settlement guaranteed the National Party and its constituency economic power, while the black majority would be given political power under the constitutional democracy. However, in order to justify this new strategy a spectacle had to be put in place. This was achieved through a series of metaphors, one of the most prominent being the fiction of the rainbow nation.

\section{Mythical rainbow(s)}

Following the end of legislated apartheid, South Africa embarked on a project of rethinking and reimagining the concept of nationality and nationhood. One of the guiding metaphors found in this project is the idea of the rainbow nation, with its most prominent vessel the new constitution. Archbishop Desmond Tutu coined the term 'rainbow nation' in 1996 when he wrote that '[w]e [South Africans] are [the] rainbow people of God' (cf. Tutu 1996). Tutu makes this claim of a rainbow nation and rainbow people of God in the same year the final draft of the Constitution of the Republic of South Africa, Act 108 of 1996, was signed by the president as well as the Truth and Reconciliation Commission (TRC) had its first hearings. This idea of the rainbow nation can be, and has indeed been, read in several ways. We would like to focus on the religious connotations of this metaphor and Archbishop Tutu's own possible religious inferences when he spoke of the rainbow nation. Apart from it aiming to represent some sort of multiracialist approach to nation building, there is a direct spatial reference to the story of Noah and the flood in the Old Testament.

The story of Noah follows the activities of the titular character (Noah) as he builds an ark to withstand the coming flood. Noah knows he has to build the ark because there is a covenant set up between God and Noah. He also needs to fill this ark with two of every animal in the world to ensure repopulation once the flood is over. The metaphor of the rainbow appears toward the end of the tale when God provides Noah with a rainbow to promise that he will never have to go through this ordeal again. Although many interpretations of this metaphor exist, it is our contention that the author draws on this image of the rainbow to attempt to signify the new day that has apparently dawned after the storm of apartheid, forgetting completely the flood that was 350 years of colonial exploitation. ${ }^{6}$ The metaphor of the rainbow has become a brand for South Africa that, along with the transformative constitution, the TRC and 22 years of democracy, became the main exports of the country.

The prevalence of the theological in the constitutional project is also marked in some of the institutions of the postapartheid space. The reverence for the holy trinity of the trias politica and the continuous reference to the constitutional document for guidance and, hopefully, redemption are prime examples of these theological metaphors. Our choice to not capitalise 'constitution' is an attempt to move away from the proper naming of the document and its imminent connection with a holy document, another reference to the theological carried by the constitution. The theological metaphors of forgiveness and reconciliation contained in the constitution can easily be counter-posed to the ideas of redistribution, return of sovereignty and reconfiliation found in the work of several African philosophers and political theorists (cf. Pheko 1990; Ramose 2002; Sobukwe 1957 [2013]).

The constitution and the democracy that it ensures offers a redemptive option for the conqueror and turns the indigenous conquered people of South Africa into perennial redeemers. ${ }^{7}$ Because the constitution (section 25) protects the right to property obtained unjustly through colonisation and then also prohibits the indigenous conquered people from taking back this property, the constitution forces the indigenous conquered peoples, by law, to continually forgive, and therefore also justify and redeem, the conqueror. Looking closer at the occurrence of the rainbow after the flood and the words used by God when addressing Noah, we see the rainbow fulfilling the same role:

This is the sign of the covenant I am making between Me and you and every living creature with you, a covenant for all generations to come: I have set My rainbow in the clouds, and it will be the sign of the covenant between Me and the earth. Whenever I bring clouds over the earth and the rainbow appears in the clouds, I will remember My covenant between Me and you and all living creatures of every kind. Never again will the waters become a flood to destroy all life. Whenever the rainbow appears in the clouds, I will see it and remember the everlasting covenant between God and all living creatures of every kind on the earth. (Genesis 9:12-14)

The rainbow forever appears in the clouds as a reminder of what was, what has passed. The constitution does exactly the same: it appears to most people as an occurrence in the clouds, a place on a mountain in Johannesburg, that acts as a continual reminder not of what was, but of what is - the continued

6 .The true intention and meaning of Archbishop Tutu's phrasing can be debated, but it is also the case that we live in an era where the author has 'died' (cf Barthes 1967; Burke 2010). Interpretation of writing or any utterance is not tied to the intention or meaning of the author in question but rather to the hermeneutic horison of the interpreter.

7.We follow MB Ramose's theorisation around the conqueror and the conquered. Accordingly, Ramose argues that all the conquered peoples of the world share the experience of being unjustly conquered by colonial conquerors. The use of 'indigenous conquered people of South Africa' refers to a shared experience of loss of sovereignty and title to land. This term includes the Bantu-speaking peoples, the Indians and the so-called coloureds of South Africa (Ramose 2001). 
conquest of the indigenous people conquered in the unjust wars of colonisation. The adoption of the constitution could not possibly address the 'original fundamental conflict of sovereign title to territory and the vital question of economic justice' (Ramose 2012:26), a necessary condition for any form of liberatory political project in South Africa.

\section{Reconciliation and sin}

These necessary conditions of the liberatory project in South Africa also correspond to Allan Boesak's thoughts on reconciliation in his sermon 'Proclamation and Protest: The Lost Sons'. In this text Boesak relays the story that appears in Luke 15:11-38. The narrative of this parable is well known and tells the story of two brothers, their relationship to their father and their inheritance. One brother claims all of his and leaves the family home, only to return a while later disgraced and asking for forgiveness. Boesak shows us how in the case of the return of the lost son, the price of real reconciliation is costly for all involved. While the younger, once wayward, brother comes home and must repent, the older brother also loses his own status and possible income now that his brother has returned. The older brother refuses to partake in the feast his father has prepared for the younger brother even though his father begs him to join. Boesak (1985:78) uses this parable to remind us that, '[f]orgiveness does not mean that sins are simply covered over, and reconciliation is never the pious concealment of guilt. Reconciliation is exposure, the unmasking of sin, and a process of restitution'. For Boesak then, reconciliation is closer to the project of liberation, since it functions on a different conceptual level than forgiveness. Reconciliation is more than forgiveness and must also contain within it justice. Boesak's (1985:78) challenge, following from this parable, is to not 'use reconciliation as an 'easy way out' [in order] to escape the pressing issues in our South African situation'. For Boesak (1985:75), 'reconciliation is costly. It presupposes alienation from others, from God, from ourselves even. We must not only face the fact of that alienation, we must also address the reasons for it'.

There is a clear reference to the liberation theology understanding of sin as structural oppression - structural sin - instead of interpersonal (non)action (Dussel 1988:18, 22-23; Faus 1996:197-200) that Boesak makes here. Accordingly, sin needs to be understood as a structural construction that allows for the domination of one group by another, the praxis of domination:

[T] he origin of evil or sin lies in a negation of the other, the other person, the other term of the person to person relationship ... Offense to God is always and antecedently an act of domination committed against one's brother or sister. God is the absolute Other; hence God is offended when we dominate in some manner the other-and-neighbour... To dominate our neighbour is to sin against God. (Dussel 1988:18-19)

Dussel (1988:21) further defines 'sin' as social or concrete and existing:

... if a person (or group of persons) stably or historically (as the encomendero dominated the Amerindian, the capitalist dominates the wage-earner, the man the woman, and so on), we may say that this praxis of domination, this defect or sin is institutional or social. It is a type of objective, real, social relationship, maintained in historical groups.

Sin can therefore be understood as being 'in relation to others' (Dussel 1988:20) and consequently in relation to God. The domination of the other can, however, not be merely individualised, as the human being is always within a social milieu: 'From the moment an individual is born, he or she will never exist apart from the institutional texture that antedates and determines this particular individual' (Dussel 1988:21). Because the individual is always within a social milieu that is structured and regulated by institutions of power, all and any 'individual inherits this institutional, 'originary' sin' (Dussel 1988:21) depending on what race, class or gender construction one is born into. José Ignacio González Faus (1996) writes that:

... where people live together they are never merely contiguous like a simple juxtaposition of stones. They are inserted into a world of mediations and institutions: family, marriage, profession, city, economy, culture, state and so on .... Therefore evil, like the human being, is never just personal, although it is also personal, and therefore any personally sinful human being is both responsible and a victim. (pp. 197-198)

Considering the above-mentioned historical narrative and discussion on structural sin, we can discern a difference in opinion regarding the concept of reconciliation between Tutu and Boesak. The specific form of reconciliation employed during the TRC, and championed by Tutu during this time, is one that individualises sin to individual actions and does not consider sin as a praxis of domination. Even when Tutu called for the imposition of a white tax it still did not move the question of reconciliation away from the individual into the social. The imposition of a white $\operatorname{tax}^{8}$ is reminiscent of the purchase of Catholic indulgences in order to emancipate the individual of their sin. What is required is a reconstitution of the state and its institutions to eradicate a historical and structural sin. Consequently, this individualised form of reconciliation, devoid of liberation, dehistoricises and depoliticises sin and locks reconciliation into a never-ending dialectic with forgiveness. The consequence of this is that structural sin still exists in the form of domination and unequal power relations between the so-called previously oppressed and their oppressors.

\section{Poverty in paradise}

It has been our argument in this paper that the colonisation and creation of South Africa were based on the annexation of property and transformation of space by an invading and conquering class. The annexation of property and transformation of space were also centred on a biopolitical division based on race. The dominated and oppressed people in South Africa have historically and politically been the indigenous conquered people. The poor in South Africa, following our discussion above, must then

8.See Williams, 'Tutu calls for wealth tax for whites', http://www.iol.co.za/capeargus/ tutu-calls-for-wealth-tax-for-whites-1116617 
also be the same indigenous conquered people. This domination and oppression is still visible today when considering the geographical allocation and division of space. The majority of people in the country, the indigenous conquered people, are still living in the same spaces, producing the same material conditions, that they did under colonialism and apartheid. It therefore follows both logically and historically that justice must be spatial and any reconciliation must be based on a spatial redivision. As pointed out above with reference to the theological metaphors in the constitution, a theological agenda has been readily employed to confuse the concepts of justice, liberation and reconciliation. The theological agenda of South Africa today is one that defends and strengthens the already existing constitutional order. The injustices prevalent in society are to be alleviated with missionarytype activities in the form of NGOs and community outreach projects, all the while allowing an undisturbed continuation in the material order of things. The overarching narrative is that the post-1994 moment is one that ushers in the era of justice and, in the words of Dussel, presents the kingdom of God as an always already present.

For Dussel, the kingdom of God is not merely a not yet but also always an already. Dussel posits a dialectic between the kingdom of God as a not yet and an already, a dialectic that cannot be separated until the moment of the eschaton, a dialectic that presents itself most clearly in the relationship between the kingdom of God and the poor (Dussel 1979:115). It is the poor - the materially excluded and oppressed in a society formed by a praxis of domination - who embody this double movement of the not yet and the already (Dussel 1979:115). The continued existence of poverty is an acute reminder that the kingdom of God is not yet and that the present cannot be fetishised (Dussel 1979:115). Poverty here must be understood in the biblical sense as denoting 'the dominated, oppressed, humiliated, instrumentalised term of the practical relationship called sin' (Dussel 1988:22). This is because:

... [the] constitutive act of the 'poor' in the Bible is not lacking goods, but being dominated, and this by the sinner. The poor are the correlative of $\sin . .$. the 'poor' are those who, in the relationship of domination, are the dominated, the instrumentalised, the alienated. (Dussel 1988:22)

For Dussel, to be poor is not merely to have a lack of material goods or possessions but rather to suffer under a specific form of oppression (Dussel 1979:120). Poverty in this sense is a human and socially constructed condition that shackles and oppresses people:

\footnotetext{
... to define poverty as a virtue or as an absolute stance towards God, as an openness to what that resembles humility, is to dissolve it in order to be able to use it as a justification of wealth. (Dussel 1979:119)
}

There is a link between the lack of material possessions that poverty has come to signify and the abundance signified by wealth: someone has a lack because something has been taken away. Poverty can be therefore not merely a mental or religious attitude; it is a position of being oppressed and exploited. The very existence of poverty is proof that there is still sin and the kingdom of God is not yet on Earth.

The continued existence of poverty is also the result of the naturalisation of the idea of poverty as a fact of everyday life and society. Dussel argues that the church, throughout its history and with its theology, has managed to separate the idea of 'materially poor' from that of 'poor in soul' (Dussel 1979:120). Because Christianity was a religion born from struggle and oppression, the moment its adherents moved out of this oppression into relative wealth and power they had to justify their own power and wealth. This happened from the fourth century onwards, when the Christianity that was once a religion of the oppressed in Egypt, the Byzantine and Roman Empires became the official religion of the new emperors after freedom was granted to Christians (Dussel 1979:117). As Christianity became the official state religion, a new question emerged in their minds and their theology: 'Can the rich be poor?' It is at this stage that there is a 'metamorphosis of the notion of the poor, as part of a metamorphosis of the City of God' (Dussel 1979:117). As Christians claimed to be building the City of God and converting those that did not yet believe the Persians to the east and the Muslim Arabs to the south they became the new oppressors and nobility of the Empire. To be poor became linked with 'intention' and 'spirit' and not material oppression, while the city of God became an idolatrous attempt at constructing a worldly kingdom of God (Dussel 1979:117).

If the church focused merely on the existing already of the kingdom of God in the world, then it would be echoing a type of Stoic or Epicurean cosmopolitanism that considered the Roman Empire as the unchanging and divine city of the gods (Dussel 1979:125). Considering the kingdom of God as a not yet would in turn merely accept the current material order as unchangeable and propagate a radical inactivity in relation to this material order. The task of the liberation theologian in this situation is, in the words of Simon Maimela (1990):

... not simply calling for an improvement in the living conditions of the oppressed, but for the end of oppression itself. Society should be organised in such a way that all people should be able to take part in determining the future shape of their society. Liberation theologians believe that if people are truly to be free, they should be able to take power into their own hands to shape their own future and create their own history, and this entails a struggle against all the forces of oppression in human society. (p. 176)

The liberation theology impetus is exactly to live within this dialectic between the already and the not yet, to realise it is inevitable but still work towards its undoing, its unshackling.

Dussel likewise argues that it is an ideological-theological trick played by the church that turns oppression and poverty into a natural social occurrence. It is this 'ideologicaltheological trick of dissolving, dis-carnating poverty' that has as its direct consequence the naturalisation of poverty, 
the belief that poverty is a natural condition of human existence, a 'reality without history' (Dussel 1979:120). This naturalisation of poverty gives rise to a logic that reacts to the existence of poverty in the form of aid or assistance from those that are 'in solidarity with the poor' and can claim that 'we are all poor'. This naturalisation of the existence of poverty obfuscates the possibility to investigate the reason for poverty's existence and 'is the first step towards the sacralisation of the existing material order' (Dussel 1979:120). For Dussel there is a need to affirm the structural existence of poverty and proceed towards critique from the position of the poor and those that are materially excluded. In the case of South Africa this critique thus has to be from the position of, and speak directly to, the indigenous conquered people.

\section{Conclusion}

Dussel's argument above presents us with a counter-view to the role of theology in post-1994 South Africa. For Dussel, the theological agenda is one that must align itself with the eradication of structural sin. The dominant, mainline theological tradition in South Africa is a theology that tells of the rainbow nation and preaches the already of liberation for the indigenous conquered people, while the majority of these same people still live in the same conditions they have been living in for the past 50 years: in shacks on the outskirts of the industrial, commercial and economic centres of the country. These conditions and the creation of poverty in South Africa can be seen as a direct result of a social and material relation of a conqueror class and a conquered class. A fundamental critique of the current in South Africa requires for an end of oppression through the reorganising of society. A realisation that the continued existence of poverty amongst the indigenous conquered people of the country indicates an outstanding question of liberation also requires the realisation that there is still an acute need for theology that 'comes from people who have become acutely aware of being oppressed and down trodden and who are no longer prepared to put up with this' (Maimela 1990:171). There is thus in our opinion a strong need to return to the basic tenants and teachings of liberation theology in order to address issues of spatial justice and the questions posed by a theology of space in South Africa.

The replacement of the ideas of liberation and justice with forgiveness and reconciliation, a replacement of political concepts with theological metaphors, is what a new theological agenda for spatial justice needs to reverse in order to sufficiently address the lingering presence of structural sin in South Africa. It is, however, our view that the questions raised by a spatial theology is best addressed through the work and mediations of liberation theology. The prioritising of the question of liberation and justice will inevitably lead to the prioritising of questions of space and land. The continued existence of structural sin is visible in the continued existence of the vastly unequal spaces inhabited by different groups of people in South Africa. To eradicate sin in South Africa thus requires a theological agenda of liberation that would include, as a fundamental part of its programme, the question of space and ownership of land. The question we want to pose for further consideration is whether a 'new' spatial theology - or contextual theology, or public theology - is required when the 'old' questions posed by liberation theology are still outstanding? Can, and do, these new theologies work towards the eradication of structural sin and oppression through the liberation of the oppressed or do they recast justice as reconciliation, reframe sin as the avarices of the human and not the fault in the system? We do not pretend to have offered any answer to these questions but at best hope to have assisted in their moment of re-emergence.

\section{Acknowledgements}

The authors thank colleagues and friends who share the journey with them every day: the thought is collective, the errors individual. P.T. Delport wants to thank the National Research Foundation.

\section{Competing interests}

The authors declare that they have no financial or personal relationships that may have inappropriately influenced them in writing this article.

\section{Authors' contributions}

P.T.D. and T.L .were co-authors of this article.

\section{References}

Anghie, A., 2004, Imperialism, sovereignty and the making of international law, Cambridge University Press, Cambridge.

Aristotle, 1962, Politics, transl. T.A. Sinclair, Penguin Books, London.

Barthes, R., 1967, 'The death of the author', viewed 18 June 2016 from http://www. ubu.com/aspen/aspen5and6/threeEssays.html\#barthes

Biko, S., 2004, I write what I like, Picador Africa, Johannesburg.

Boesak, A., 'Proclamation and protest: The lost sons', in C. Villa-Vicencio \& J.W. De Gruchy (eds.), Resistance and hope: South African essays in honour of Beyers Naude. David Phillip Publisher, Cape Town.

Boff, C., 1996, 'Methodology of the theology of liberation', in J. Sobrino \& I. Ellacuría (eds.), Systematic theology: Perspectives from liberation theology, pp. 1-21, SCM Press, London.

Burke, S., 2010, The death and return of the author: Criticism and subjectivity in Barthes, Foucault, and Derrida, 3rd edn., Edinburgh University Press.

Dussel, E., 1979, 'The Kingdom of God and the Poor', International Review of Mission 68(270), 115-130. http://dx.doi.org/10.1111/j.1758-6631.1979.tb01301.x

Dussel, E., 1985, Philosophy of liberation, transl. A. Martinez \& C. Morkovsky, Wipf \& Stock, Eugene OR.

Dussel, E., 1988, Ethics and community, transl. R.R. Barr, Wipf \& Stock, Eugene, OR.

Fanon, F., 2001, The wretched of the earth, transl. C. Farrington, Penguin, London.

Faus, J.I.G., 1996, 'Sin', in J. Sobrino \& I. Ellacuría (eds.), Systematic theology: Perspectives from liberation theology, pp. 194-204, SCM Press, London.

Hansen, M.H., 1992, 'The tradition of the Athenian democracy AD 1750-1990', Greece and Rome 39(1), 14-30.

Hunt, P., 2002, Slaves, warfare, and ideology in the Greek historians, Cambridge University Press, Cambridge.

Kennedy, D., 1986, 'Primitive legal scholarship', Harvard International Law Journa 27(1), 1-98.

Lephakga, T., 2012, 'The significance of justice for true reconciliation on the land question in the present day South Africa', Unpublished Masters dissertation, UNISA, Pretoria.

Lephakga, T., 2013, 'The history of theologised politics in South Africa, the 1913 Land Act and its impact on the flight from the black self', Studia Historiae Ecclesiasticae 39(2), 379-400.

Lephakga, T., 2015, 'Dealing lightly with the wounds of my people: A theological ethical critique of the South African truth and Reconciliation Commission', PhD dissertation, UNISA, Pretoria. 
Maimela, S., 1990, Modern trends in theology, Skotaville Publishers, Johannesburg. Murray, J., 1991, The landscape of alienation: Ideological subversion in Kafka, Céline, and Onetti', Stanford University Press, Stanford.

Pheko, M., 1986, Apartheid: The story of a dispossessed people, Marram Books, London.

Pheko, S.E.M., 1990, South Africa: Betrayal of a colonised people: Issues of international human rights law, Skotaville Publishers, Johannesburg.

Plato, 2007, The Republic, transl. D. Lee, Penguin, New York.

Ramose, M.B., 2001, 'An African perspective on justice and race', Polylog: Forum for Intercultural Philosophy, vol 3, viewed 18 June 2016 from http://them.polylog. org/3/frm-en.htm\#s7

Ramose, M.B., 2002, 'I conquer, therefore I am the sovereign: Reflections upon sovereignty, constitutionalism, and democracy in Zimbabwe and South Africa', in P.H. Coetzee \& A.P.J. Roux (eds.), Philosophy from Africa: A Text with Readings, pp. 463-500, Oxford University Press, Oxford.

Ramose, M.B., 2012, 'Reconciliation and Reconfiliation', African Journal of Philosophy 5,26 .
Scheidel, W., 2008, The comparative economics of slavery in the Greco-Roman world, Princeton/Stanford Working Papers in Classics Paper No. 110504, SSRN, viewed 18 June 2016 from http://ssrn.com/abstract=1096417

Schmitt, C., 2006, The nomos of the earth in the international law of the jus publicum europaeum, transl. G.L. Ulmen, Telos Press, New York.

Sobukwe, R.M., 1957 [2013], 'The Nature of the Struggle Today', in Karis, T.G, and Gerhardt, G.M. (eds.), From protest to challenge: A Documentary History of African Politics in South Africa, 1882-1990, Volume 3: Challenge and Violence, 1953-1964, Jacana, Auckland Park.

Terreblanche, S.J., 2002, A history of inequality in South Africa 1652-2002, University of Kwazulu Natal Press, Pietermaritzburg.

Tutu, D., 1996, The rainbow people of god: The making of a peaceful revolution, Doubleday, New York.

Webster, E., 1983, 'Background to the supply and control of labour on the gold mines', in E. Webster (ed.), Essays in Southern African Labour History, pp. 9-19, Ravan Press, Johannesburg.

Williams, M., 2011, 'Tutu calls for wealth tax for whites', in The Daily Maverick, viewed 18 June 2016 from http://www.iol.co.za/capeargus/tutu-calls-for-wealth-tax-forwhites-1116617 